\title{
THE LEVEL OF USE OF PUBLIC RELATIONS TOOLS AND EVALUATION OF THEIR IMPACT ON THE REPUTATION OF CHEMICAL COMPANIES FROM THE PERSPECTIVE OF THE CZECH PUBLIC
}

\author{
Martina Jelinkova ${ }^{1}$, Hana Lostakova ${ }^{2}$, Katerina Machackova ${ }^{3}$ \\ Department of Economy and Management of Chemical and Food Industry, Faculty of Chemical Technology, \\ University of Pardubice, Studentská 95, Pardubice, Czech Republic \\ E-mails: ${ }^{1}$ martina.jelinkova@upce.cz (correspondingauthor); ${ }^{2}$ hana.lostakova@upce.cz; \\ 3st50347@student.upce.cz
}

Received 05 March 2020; accepted 06 May 2020

\begin{abstract}
The article presents the results of primary quantitative research aiming to determine the extent to which PR tools are used by chemical companies towards the public (wide and local) in the Czech Republic. It was found that, in the opinion of the respondents, the natural publicity of the company through word of mouth and media information has the greatest influence on public opinion, while the influence of social networks has not been appreciated yet. An important contribution of the paper may be the identification of the extent of use of a complex set of PR tools in the areas of information publicity, events and corporate social responsibility initiatives (CSR) recommended by literature to support business reputation among the public. Thus, it was possible to identify PR tools often used by companies, albeit not very effective, and vice versa, those PR tools that are perceived to be effective, but not yet widely used in practice. The application of research results will facilitate a better allocation of company resources among PR tools in order to more effectively meet the company's PR objectives towards the public. The research was conducted through the electronic questioning method and involved 53 marketing and PR managers of chemical companies in the Czech Republic.
\end{abstract}

Keywords: publix relations, reputation, chemical industry, Czech public, public relations tools.

JEL Classification: L14, L65, M31.

\section{Introduction}

An important intangible asset in current markets is the reputation of the company based on mutual trust between partners. In particular, direct relationships with customers or employees of the company are still essential, but due to the growing competition and accelerated communication exchange, relationships with more distant stakeholders, including the public, are gaining importance. This is also felt by purely industrial companies trading mainly on B2B markets. Positive public perception of these companies is reflected not only in their better position in the labour market, but it also facilitates the cooperation of the company with other entities within the region or country. Public relations (PR) instruments have traditionally been among the basic tools for creating a positive image and, subsequently, reputation of businesses in the eyes of the public. As previous research suggests (e.g. Sommerfeldt et al., 2019; Rubtcova \& Pavenkov, 2018; Page \& Parnell, 2018; Cepova, 2017; Jelinkova et al., 2017), there are many PR tools recommended by literature and used by companies and it seems that for each stakeholder group it is possible to choose a different combination to maximize their effectiveness. In our paper we first map modern approaches and trends in PR. Subsequently, we specify the communication channels and PR tools recommended by literature for creating a positive perception of the company in the eyes of the local and general public. That search became the basis of our primary research, the aim of which was to find out which communication channels and PR tools are used by industrial enterprises to influence the public and what their perceived effectiveness is for creating positive relations between business and the local and general public. The research was focused on chemical industrial enterprises in the Czech Republic, however, given the global markets in industrial practice, similar results can be expected in the international context as well. We believe that the results of our research provide both theoretical and practical benefits for effective planning and use of the most effective combination of PR tools specifically designed to develop a positive reputation for industrial companies among the general and local public. 


\section{Theoretical framework}

\subsection{Current conception of $P R$ and trends of its development}

It can be argued that views and opinions on PR have evolved. The oldest definitions and approaches to PR perceived the public as a passive recipient of information from the company and PR was defined as one-way and compelling informative communication aimed at influencing public opinion. In the second half of the twentieth century, however, the public is beginning to be perceived as an audience actively involved in receiving news. Therefore, the goal of PR is no longer just to convince, but there is an effort to create a relationship where the mutual influence between the company and the public is favourable for both parties, i.e. a "win-win" relationship is established. Oliveira and Capriotti (2019) analysed 86 definitions of public relations from the world literature from the early efforts to define it and found that the vast majority of older definitions (prior to 1970s) focused on the general purpose of "persuasion", whereas most of the definitions obtained from the 1970s and 1980s to the present day focus on the idea of "establishing a relationship". To express this purpose, the main terms used by the authors in the definitions are, inter alia, "mutual benefit", "mutual understanding", "mutual trust". This corresponds to the modern definition of PR from the Public Relations Society of America, which reads as follows: "Public relations is a strategic communication process that builds mutually beneficial relationships between organizations and their public" (About Public Relations, 2019). Cuenca (2012) but it points out that while in the professional literature the definition of the purpose of PR has clearly shifted from persuasion to establishing relationships, this may not always be the case in practice as the practical effectiveness of PR programs is often measured mainly by analysing and verifying the impact and influence of the company on public opinion.

Some authors, such as Fawkes (2019), have examined $\mathrm{PR}$ in an international comparison, claiming that this term is used in different contexts in different countries. It is often used as a synonym for organizational communication, corporate communication, communication management and strategic communication (Cornelissen, 2011; Heath \& Gregory, 2015). This, according to Fawkes (2019), makes it difficult for scientists to explore the field and be well versed in it. It is especially because some perceive PR only as a business function while others develop it in a social and cultural context (Edwards, 2018). Another problem is that, in practice, public relations often interfere with other communication functions, especially marketing. But if we accept the definition by Kotler and Armstrong (2017), marketing is a function that builds value for customers by managing positive relationships with them. Then, from a PR perspective, stakeholders include potential and existing customers, and the relationships with these groups are often managed simultaneously through public relations and marketing (Gesualdi, 2019).

Developing mutual dialogue between the company and the public is crucial for establishing relationships. This is currently greatly facilitated by modern means of communication that enable interactivity. However, the presence of interactive elements or features on the organization's website and social media accounts is not evidence of dialogue (Sommerfeldt \& Yang, 2018). "Simply communicating is not enough and a deeper level of audience interaction is expected - and often demanded...we must be able to engage across all channels, at all times, in all manner of ways..." (Friend \& Shandwick, 2012). Engagement of communication partners must be achieved (Men \& Tsai, 2014; Taylor \& Kent, 2014). Although the importance of engagement studies has been increasing lately, it is not yet clear what this term is supposed to mean (Morehouse \& Saffer, 2019). Experts often consider engagement to be a measurable variable while trying to determine the level of engagement between organizations and stakeholders. This is often associated with interactivity and digital dialogue communication where engagement is measured in response to tweets, comments, or as a cognitive, attitude or behavioural dimension (Men \& Tsai, 2016). It should be remembered that technological innovation is continuing and changing communication processes. New trends, such as artificial intelligence, large data and machine learning, may pose new questions and challenges to dialogical communication and may require the theory to evolve and adapt (Sommerfeldt \& Yang, 2018). New trends in this regard are indicated, for example, by Amodu et al. (2019), who define the so-called "Smart-PR". The authors argue that in Smart-PR, we need to make much better use of the fact that smart devices connected to the Internet are constantly generating user data and communicating with other devices. In this way, the company can easily obtain information about the needs, habits and requirements of its stakeholders and use it for communication and relationship building.

Some authors, such as Brunner and Smallwood (2019), highlight the so-called "public interest" as the central idea and meaning of modern PR, 
which, according to the authors, has not yet been given enough attention to in relation to PR. The authors present the Public Interest Relationship (PIR) concept whereby PR professionals should feel as a civic duty to create space for dialogue, to support and listen to different opinions and to conduct their fair analysis and synthesis, which should lead them to recommendations promoting public interest. They should act in public interest but at the same time achieve the company's goals. Only PIR applied in this way leads to increased trust towards the company, community formation and development of a positive reputation. At the same time, it is important that the communication and behaviour of the company be perceived as authentic. This can only be achieved if the company behaves ethically, transparently and appropriately demonstrates its good intentions (Bowen et al., 2016). For this purpose, PR can use a wide range of communication channels as well as specific tools.

\subsection{Communication channels for public relations}

Correct selection of communication channels through which information flows between communication partners is crucial for the effective functioning of PR communication. The process of selecting strategic channels within PR is referred to as "media planning" or as deciding on the "media mix" of the public relations program (Hallahan, 2001). Historically, the use of communication channels for public relations reflects the spread of new communication technologies. The advent and popularization of the Internet and related digital communication technologies have created a number of new channels from which PR professionals can choose. The most commonly used are websites, banners, e-mails, which are usually used mainly for one-sided communication, but also tools for dialogue - social networks, videos, blogs and podcasts (sometimes referred to as audio blogs) (McIntosh, 2005; Tworzydło, 2016).

It is obvious that social media enable two-way communication much better than traditional media channels such as newspapers, radio and television. (such as Avidar et al., 2015). However, research suggests that there is no "active" dialogue between organizations and the public through social networks (Kennedy \& Sommerfeldt, 2015; Theunissen \& Noordin, 2012). Still, the interactivity and popularity of major social networks enabled companies to "connect" with the public (Smith, 2010), create communities (Lovejoy et al., 2012), but also engage the public in communication and monitor its immediate responses (Saxton \& Waters, 2014). One of the great advantages of these Internet-based technologies is the ability to address precisely defined target audiences of the public with messages tailored to their needs and expectations. Online communications can also be presented very quickly and at low cost. The problem is the high frequency of change within these communication tools, which requires continuous monitoring and rapid adaptation. Another threat is the easier emergence of "crises" in the online environment. Bad news spreads much faster here and has a stronger and more severe impact than in the non-Internet environment. The weakening of direct personal relationships and contacts is also a barrier. (Tworzydło, 2016) For this reason, non-mediated channels of communication will also play a role in public relations - a real interpersonal dialogue (Kent \& Taylor, 2002), both with company employees and word of mouth.

It is obvious that the importance of traditional communication channels generally decreases. For example, experts no longer believe that traditional media is an important way of spreading the company's pro-social or environmental activities (Sommerfeldt et al., 2019). An important role in informing the public about corporate social responsibility is played not only by websites or social networks (Tetrevova et al., 2019), but also by company annual reports, voluntary CSR reports, voluntary environmental reports and corporate promotional materials and printed materials (e.g. newspapers), which are often distributed online (Tetrevova, 2018).

However, research by Sommerfeldt et al. (2019) suggests that the use of various communication channels by current experts cannot be described as a mere "exchange" where new media replace old ones (Yuan, 2011), nor as a combination or "integration" of traditional and new media. Instead, practitioners tend to group essentially different types of media channels into different groups and use them for different communication purposes. Experts seem to select media groups based on the different needs in developing the relationship and the desired outcomes (Sommerfeldt et al., 2019).

\subsection{PR tools recommended for creating positive business perception in the eyes of the local and general public}

It is clear from the previous chapters that the implementation of the PR program involves the use of various public relations tools, the selection of which is dictated by the specifics of strategic ob- 
jectives and expected results (Rubtcova \& Pavenkov, 2018). In relation to the external public of the company, these are means of the so-called external PR, which are dealt with by a number of authors, e.g. Rubtcova and Pavenkov (2018), Smith (2017), Page and Parnell (2018) etc. Based on modern research (e.g. Sommerfeldt et al., 2019), it can be argued that the use of a range of PR tools will be specific to a particular target group of the public and probably also to certain types of businesses or industries. Based on the opinions contained in the available literature and also according to our own research (e.g. Cepova, 2017; Jelinkova et al., 2017), we have proposed a set of PR tools that can be recommended for deepening the relationship of industrial enterprises with the local and general public. In our opinion, these PR tools can be divided into three groups:

General PR tools: press releases; press conferences; annual reports; company newspapers and magazines, bulletins (usually printed version), newsletters (usually electronic version); internet presentation of the company; occasional publications (anniversary prints, business anniversary video or audio recordings, etc.); advertising of the company (billboards, flyers, posters, banners, etc. promoting the company, not the products) and identity media (uniform visual elements - employees' clothing, office and shop equipment, appearance of buildings, logos, graphic harmonization of packaging, printed materials)...., but also sound signals).

PR events: business presentation events; thematic conferences or symposia; company days or lectures, company workshops; organization of social events and meetings aimed at the local as well as the general public; organization of events aimed at the start-up of an entity or its branch; open days; charitable auctions or events; sponsorship of cultural, political, sports and social events.

Presentation of Social Responsibility Activities: presentation of information on business activities and financial results; presentation of information about the company care for employees (e.g. information about the quality of the working environment, about OSH, about employee benefits, etc.); presentation of information about the company's care for the environment (e.g. information on energy savings, waste minimization, investments in environmental protection, etc.); presentation of information on conducting and promoting the ethical conduct of your business (e.g. information on the development and application of a code of ethics, evidence of your business ethics, etc.); presentation of information about your company's chari- table activities (e.g. information about donations to foundations, charitable organizations or funds, voluntary work of employees, donations, etc.).

Subsequently, we decided to use primary quantitative research to find out which of these PR tools are most commonly used in industrial practice and what is their perceived impact on the development of relations between the enterprise and the local and general public. The results of our research are presented in the following chapters.

\section{Research on the use of Public Relations tools and assessment of their impact on the reputa- tion of chemical companies in the eyes of the Czech public}

\subsection{Research methodology}

Primary quantitative research was carried out in 2019 by the electronic questioning method. The respondents were managers, employees of marketing and sales departments and employees of the press department or PR of chemical industrial companies associated in the Association of Chemical Industry of the Czech Republic. The association was chosen for our research since its members represent more than 60 per-cent of the workers and more than 70 percent of the total production to the chemical, pharmaceutical, petrochemical and plastics and rubber industries on which our research was focused. In addition, it was possible to expect a higher return when questioning in associated companies, as the Association of Chemical Industry of the Czech Republic is contractually bound with our department. First, a database of all manufacturing companies associated in the Association was created, consisting of about 80 companies. Respondents from individual companies were selected by deliberate judgments when a database of e-mail addresses of suitable respondents was created based on personal contacts and analysis of websites of companies associated in the Association of Chemical Industry. The database consisted of about 250 e-mail addresses. Some respondents were contacted personally, others by telephone, and subsequently sent an electronic questionnaire with a request for completion. Answers were received from 53 respondents - managers (46 percent), marketing and sales employees (46 percent), and press department and PR employees ( 8 percent). The rate of return was approximately 20 percent.

Each of the respondents received an e-mail asking to fill in the attached electronic questionnaire. The questionnaire was compiled on the basis 
of available literature and own research (see Chapter 2.3). In the first part of the questionnaire there was a question about the communication channels used between the company and the general and local public. The main part of the questionnaire can be divided into two parts. First, the level of use of individual PR tools in the monitored companies was examined against target groups of the public, and subsequently the respondents were asked about the perceived impact of these tools on the relationship between the company and the public. The results were statistically processed using the IBM SPSS Statistics program and are presented below.

\subsection{Research results}

The introductory question was aimed at finding out to what extent, in the opinion of respondents, the public (especially the inhabitants of the region, but also of the country) uses or does not use these sources of information to get the picture of the reputation of a chemical industrial enterprise. The evaluation was carried out on a four-stage scale where $1=$ not used at all; $2=$ rather not used; $3=$ rather used; $4=$ definitely used. The results are presented in Table 1, where the evaluated sources of information (communication channels) are ranked in descending order according to the achieved average of the evaluations.

Table 1 clearly shows that the representatives of chemical industrial enterprises believe that the public draws information about their enterprises mainly from personal immediate experience and communication in combination with classic media news and internet sources (business websites, links in search engines). Interestingly, social networks are not yet seen as a very important source of information. Still, it can be assumed that their influence and importance will grow in the future. So far, voluntary CSR reports are perceived as abovestandard information sources intended primarily for the professional public, which do not influence the general public opinion much.

Another part of the questionnaire was devoted to finding out to what extent the monitored companies use or do not use specific specified PR tools to strengthen the public's (especially the inhabitants of the region, but also those of the country) positive view of the company. The evaluation was carried out on a scale where $1=$ not used at all; $2=$ partly used; $3=$ fully used. Table 2 shows the resulting placings of the monitored PR tools created by their ranking in descending order according to the achieved average rating.
Table 1. Opinions on the extent to which local and general public use sources of business information

\begin{tabular}{|l|c|c|}
\hline \multicolumn{1}{|c|}{$\begin{array}{c}\text { Source of information - } \\
\text { communication channel }\end{array}$} & $\begin{array}{c}\text { Ave- } \\
\text { rage }\end{array}$ & $\begin{array}{c}\text { Me- } \\
\text { dian }\end{array}$ \\
\hline $\begin{array}{l}\text { Word of mouth - i.e. what is said } \\
\text { about the company among people. }\end{array}$ & 3.28 & 3 \\
\hline Own experience with the company & 3.26 & 3 \\
\hline $\begin{array}{l}\text { Media - information from the press, } \\
\text { radio and television }\end{array}$ & 3.00 & 3 \\
\hline Internet & 2.94 & 3 \\
\hline Website of the company & 2.94 & 3 \\
\hline $\begin{array}{l}\text { Personal communication with com- } \\
\text { pany employees }\end{array}$ & 2.89 & 3 \\
\hline Social networks & 2.49 & 2 \\
\hline $\begin{array}{l}\text { Corporate promotional materials and } \\
\text { printed materials (e.g. newspapers) }\end{array}$ & 2.47 & 2 \\
\hline Annual reports of the company & 2.15 & 2 \\
\hline $\begin{array}{l}\text { Voluntary environmental reports of } \\
\text { the company }\end{array}$ & 2.08 & 2 \\
\hline $\begin{array}{l}\text { Voluntary corporate social responsi- } \\
\text { bility reports of the company }\end{array}$ & 1.94 & 2 \\
\hline
\end{tabular}

Table 2. Utilization rate of monitored PR tools in surveyed enterprises

\begin{tabular}{|l|c|c|}
\hline \multicolumn{1}{|c|}{ PR tool } & $\begin{array}{c}\text { Ave- } \\
\text { rage }\end{array}$ & $\begin{array}{c}\text { Me- } \\
\text { dian }\end{array}$ \\
\hline Internet presentation of the company & 2.45 & 2 \\
\hline Annual reports & 2.23 & 2 \\
\hline Sponsorship of sporting events & 2.23 & 2 \\
\hline Corporate presentation events & 2.19 & 2 \\
\hline $\begin{array}{l}\text { Presentation of environmental infor- } \\
\text { mation about your business (e.g. in- } \\
\text { formation on energy savings, waste } \\
\text { minimization, environmental invest- } \\
\text { ments, etc.) }\end{array}$ & 2.15 & 2 \\
\hline $\begin{array}{l}\text { Corporate newspapers and maga- } \\
\text { zines }\end{array}$ & 2.13 & 2 \\
\hline $\begin{array}{l}\text { Occasional publications - anniver- } \\
\text { sary prints, video or audio recordings } \\
\text { for the anniversary of the company, } \\
\text { etc. }\end{array}$ & 2.13 & 2 \\
\hline Press releases & 2.04 & 2 \\
\hline $\begin{array}{l}\text { Organization of social events and } \\
\text { meetings }\end{array}$ & 2.09 & 2 \\
\hline Sponsoring of cultural events & 2.09 & 2 \\
\hline Sponsorship of social events & 2 \\
\hline $\begin{array}{l}\text { Presentation of information about } \\
\text { your company's charitable activities } \\
\text { (e.g. information about donations to } \\
\text { foundations, charitable organizations } \\
\text { or funds, volunteer work, donations, } \\
\text { etc.) }\end{array}$ & 2.09 & 2 \\
\hline
\end{tabular}


End of Table 2

\begin{tabular}{|l|c|c|}
\hline \multicolumn{1}{|c|}{ PR tool } & $\begin{array}{c}\text { Ave- } \\
\text { rage }\end{array}$ & $\begin{array}{c}\text { Me- } \\
\text { dian }\end{array}$ \\
\hline Thematic conferences or symposia & 2.04 & 2 \\
\hline Open days & 2.04 & 2 \\
\hline $\begin{array}{l}\text { Business advertising - billboards, } \\
\text { flyers, posters etc. promoting the } \\
\text { company, not the products }\end{array}$ & 2.02 & 2 \\
\hline $\begin{array}{l}\text { Presentation of information about } \\
\text { your company's care for employees } \\
\text { (e.g. information about the quality of } \\
\text { the working environment, about } \\
\text { OSH, employee benefits, etc.) }\end{array}$ & 2.00 & 2 \\
\hline $\begin{array}{l}\text { Company days or lectures, company } \\
\text { workshops }\end{array}$ & 1.98 & 2 \\
\hline $\begin{array}{l}\text { Organization of events aimed at the } \\
\text { start-up of an entity or its branch }\end{array}$ & 1.96 & 2 \\
\hline $\begin{array}{l}\text { Presentation of information on con- } \\
\text { ducting and promoting your business } \\
\text { ethical behaviour (e.g. information } \\
\text { on creating and applying a code of } \\
\text { ethics, evidence of your business } \\
\text { ethics }\end{array}$ & 1.96 & 2 \\
\hline $\begin{array}{l}\text { Presentation of information on busi- } \\
\text { ness activities and financial results }\end{array}$ & 1.94 & 2 \\
\hline $\begin{array}{l}\text { Identity media - uniform visual or } \\
\text { audio elements }\end{array}$ & 1.89 & 2 \\
\hline Bulletins, newsletters & 1.70 & 2 \\
\hline Press conferences & 1.60 & 2 \\
\hline $\begin{array}{l}\text { Organization of charitable events or } \\
\text { auctions }\end{array}$ & 1.45 & 1 \\
\hline Sponsorship of political events & 1.36 & 1 \\
\hline
\end{tabular}

Based on the results shown in Table 2, it can be argued that the monitored enterprises use almost all of the specified PR tools to a greater or lesser extent to influence the public. The only exception is the organization of charitable events or auctions, which 68 percent of respondents do not use at all (only 6 percent of respondents use it fully) and sponsorship of political events, which even 72 percent of respondents do not use at all (8 percent use it fully). By contrast, up to 98 percent of respondents said they were using the company's online presence either fully (47 percent) or at least partially (51 percent).

The ultimate aim of our research was to find out what impact the following PR tools have or do not have, according to the experience of the interviewed managers, on the public (especially the inhabitants of the region, but also the country) in forming their opinion. The evaluation was performed on a scale where $1=$ no impact, $2=$ rather minor impact; 3 = rather major impact; $4=$ major impact. The results are summarized in Table 3, in which the evaluated PR tools are ranked in descending order so that their perceived impact on the public gradually decreases. The ranking is compiled on the basis of an average rating of each PR tool.

Table 3. Evaluation of PR tools impact on public perception of chemical enterprise

\begin{tabular}{|l|c|c|}
\hline \multicolumn{1}{|c|}{ PR tool } & $\begin{array}{c}\text { Ave- } \\
\text { rage }\end{array}$ & $\begin{array}{c}\text { Me- } \\
\text { dian }\end{array}$ \\
\hline $\begin{array}{l}\text { Company's environmental care (e.g. } \\
\text { energy savings, waste minimization, } \\
\text { environmental investments, etc.) and } \\
\text { informing the public about it }\end{array}$ & 3.23 & 3 \\
\hline Open days & 3.06 & 3 \\
\hline Sponsorship of sporting events & 2.98 & 3 \\
\hline $\begin{array}{l}\text { Creation of a quality system of care } \\
\text { for employees (e.g. pleasant work- } \\
\text { ing environment, ensuring occupa- } \\
\text { tional health and safety, employee } \\
\text { benefits, etc.) and informing the } \\
\text { public about it }\end{array}$ & 2.94 & 3 \\
\hline Internet presentation of the company & 2.89 & 3 \\
\hline $\begin{array}{l}\text { Company's charitable activities (e.g. } \\
\text { contributions to foundations, chari- } \\
\text { table organizations or funds, volun- } \\
\text { tary work of employees, donations, } \\
\text { etc.) }\end{array}$ & 2.87 & 3 \\
\hline Sponsorship of social events & 2.81 & 3 \\
\hline Press releases & 2.79 & 3 \\
\hline $\begin{array}{l}\text { Corporate presentation events } \\
\text { Company days or company lectures, } \\
\text { workshops }\end{array}$ & 2.79 & 3 \\
\hline $\begin{array}{l}\text { Business advertising - billboards, } \\
\text { flyers, posters, etc. promoting the } \\
\text { company, not the products }\end{array}$ & 2.77 & 3 \\
\hline Sponsoring of cultural events & 2.77 & 3 \\
\hline $\begin{array}{l}\text { Organizing social events and meet- } \\
\text { ings }\end{array}$ & 2.75 & 3 \\
\hline $\begin{array}{l}\text { Fair, transparent financial state- } \\
\text { ments and their presentation }\end{array}$ & 2.71 & 3 \\
\hline $\begin{array}{l}\text { Implementation of and support to } \\
\text { the ethical behaviour of the compa- } \\
\text { ny (e.g. creation and application of } \\
\text { the code of ethics, business ethics, } \\
\text { etc.) and informing the public about } \\
\text { it }\end{array}$ & 2.69 & 3 \\
\hline Thematic conferences or symposia & 2.57 & 3 \\
\hline
\end{tabular}


End of Table 3

\begin{tabular}{|l|c|c|}
\hline \multicolumn{1}{|c|}{ PR tool } & $\begin{array}{c}\text { Ave- } \\
\text { rage }\end{array}$ & $\begin{array}{c}\text { Me- } \\
\text { dian }\end{array}$ \\
\hline $\begin{array}{l}\text { Complete, transparent presentation } \\
\text { of the ownership structure of the } \\
\text { company }\end{array}$ & 2.52 & 3 \\
\hline $\begin{array}{l}\text { Corporate newspapers and maga- } \\
\text { zines }\end{array}$ & 2.49 & 3 \\
\hline $\begin{array}{l}\text { Transparent presentation of business } \\
\text { management }\end{array}$ & 2.42 & 2.5 \\
\hline $\begin{array}{l}\text { Identity media - uniform visual or } \\
\text { audio elements }\end{array}$ & 2.40 & 2 \\
\hline Press conferences & 2.36 & 2 \\
\hline $\begin{array}{l}\text { Occasional publications - anniver- } \\
\text { sary prints, video or audio record- } \\
\text { ings for the anniversary of the com- } \\
\text { pany, etc. }\end{array}$ & 2.36 & 2 \\
\hline Annual reports & 2.26 & 2 \\
\hline Bulletins, newsletters & 2.13 & 2 \\
\hline Sponsorship of political events & 1.96 & 2 \\
\hline
\end{tabular}

Table 3 demonstrates that the tools with the greatest perceived influence include the implementation and presentation of some corporate social responsibility (CSR) activities - particularly in the areas of environmental, social and philanthropic responsibility. On the other hand, according to the respondents, traditional PR tools, such as identity media, press conferences, occasional publications, annual reports and newsletters, have the least perceived impact on today's public.

\section{Conclusions}

Research into the practical use of communication channels and PR tools to create public relations among managers of Czech chemical industrial enterprises has produced mainly the following interesting findings:

- Managers believe that communication channels that are at least seemingly independent of the company's will - word of mouth and media - have the greatest impact on public opinion. On the other hand, tools intentionally employed by the company (e.g. promotional materials or news) have less influence on the public. We believe that in terms of communication channels in relation to the public, it would be appropriate to make better use of the potential of social networks, which is not yet appreciated in industrial practice.

- In the opinion of the interviewed managers, it is the internet presentation of the company, sponsoring of sporting events and realization and presentation of information on environmental care that are the most frequently used and at the same time the most effective PR tools in relation to the public.

- Annual reports, corporate newspapers and magazines, as well as occasional publications, can be seen as tools that are often used by businesses but less effective towards the public. On the other hand, open days, the creation of a quality system of employee care and information and the implementation of charitable activities of the company are PR activities with a high perceived impact on the public; despite that, they are practically implemented less often by the companies.

- Identity media, bulletins, newsletters, press conferences and sponsorship of political events are rarely used by the companies and are not considered effective in public relations.

Obviously, our research was limited to a relatively narrow group of respondents from a specific industry. Nonetheless, we believe that it has provided an interesting insight into the issue of PR, particularly for those businesses operating in socially sensitive sectors where public perception is of particular importance. Undoubtedly, the chemical industry is one of them. The research clearly shows that some traditional PR tools are less effective from today's perspective, while others are, according to the respondents, overlooked. We see the greatest potential mainly in the expansion of communication activities in the field of CSR (except for environmental responsibility), which is effective from the perspective of companies, but not so widespread yet. We believe that our research provides managers with interesting information for planning and implementing effective PR activities and communicating them to the general and local public. Only a meaningfully grouped mix of instruments specifically targeted to the PR target groups will allow an efficient allocation of the company's limited resources. It would certainly be interesting for future research to expand the number of respondents so that it is possible to efficiently perform cluster or factor analysis of PR tools and to specify different groups of tools according to different functional areas of the company or different perceived goals. With a larger number of respondents, it would certainly be interesting to analyse differences in perception by different groups of respondents - e.g. by respondent's age, 
size of company, managerial position, etc. It would certainly be appropriate to verify the conclusions with more research extending to other industries.

\section{Funding}

This work was supported by University of Pardubice, Student Grant Competition: Research in Selected Areas of Environmental Engineering and Modern Value Management Procedures Contribution [SG301003].

\section{References}

About Public Relations. (2019). Retrieved February 2, 2020, from https://www.prsa.org/about/all-about$\mathrm{pr}$

Amodu, L., Omojola, O., Okorie, N., Adeyeye, B., \& Adesina, E. (2019). Potentials of Internet of Things for effective public relations activities: Are professionals ready? Cogent Business \& Management, 6 , 1683951. https://doi.org/10.1080/23311975.2019.1683951

Avidar, R., Ariel, Y., Malka, V., \& Levy, E. C. (2015). Smartphones, publics, and OPR: Do publics want to engage? Public Relations Review, 41, 214-221. https://doi.org/10.1016/j.pubrev.2014.11.019

Bowen, S. A., Hung-Baesecke, C. F., \& Chen, Y. R. (2016). Ethics as a precursor to prganizationpublic relationships: building trust before and during the OPR model. Cogent Social Sciences, 2, 1141467. https://doi.org/10.1080/23311886.2016.1141467

Brunner, B. R., \& Smallwood, A. M. K. (2019). Prioritizing public interest in public relations: public interest relation. Public Relations Inquiry, 8, 245264. https://doi.org/10.1177/2046147X19870275

Cepova, J. (2017). Use of public relations for building a positive reputation chemical industrial enterprises (Diploma theses). University of Pardubice.

Cornelissen, J. P. (2011). Corporate communication: a guide to theory and practice (3rd ed.). Sage.

Cuenca, J. (2012). Las auditorías de relaciones públicas (1st ed.). UOC.

Edwards, L. (2018). Understanding public relations: theory, culture and society (1st ed.). Sage.

Fawkes, A. G. J. (2019). A global capability framework: reframing public relations for a changing world. Public Relations Rewiew, 45, Article 101781. https://doi.org/10.1016/j.pubrev.2019.05.002

Friend, R., \& Shandwick, W. (2012). The era of engagement. In $P R$ Week.

https://www.prweek.com/article/1141931/eraengagement

Gesualdi, M. (2019). Revisiting the relationship between public relations and marketing: encroach- ment and social media. Public Relations Review, 45, 372-382.

https://doi.org/10.1016/j.pubrev.2018.12.002

Hallahan, K. (2001). Strategic media planning: toward an integrated public relations media model. In Handbook of public relations (pp. 461-470). Sage. https://doi.org/10.4135/9781452220727.n38

Heath, R. E., \& Gregory, A. (2015). Sage benchmarks in communication (1st ed.). Sage.

Jelinkova, M., Lostakova, H., \& Cepova, J. (2017). Utilization of PR tools within building a positive reputation of Czech chemical companies. In 4th International Multidisciplinary Scientific Conference on Social Sciences and Arts "SGEM 2017" (pp. 1117-1124). Sofia: STEF92 Technology Ltd. https://doi.org/10.5593/sgemsocial2017/15/S05.140

Kennedy, A. K., \& Sommerfeldt, E. J. (2015). A postmodern turn for social media research: theory and research directions for public relations scholarship. Atlantic Journal of Communication, 23, 31-45. https://doi.org/10.1080/15456870.2015.972406

Kent, M. L., \& Taylor, M. (2002). Toward a dialogic theory of public relations. Public Relations Review, 28, 21-37. https://doi.org/10.1016/S0363-8111(02)00108-X

Kotler, P., \& Armstrong, G. (2017). Principles of marketing (17th ed.). Pearson Education.

Lovejoy, K., Waters, R. D., \& Saxton, G. D. (2012). Engaging stakeholders through twitter: how nonprofit organizations are getting more out of 140 characters or less. Public Relations Review, 38, 313-318. https://doi.org/10.1016/j.pubrev.2012.01.005

McIntosh, S. (2005). Blogs: has their time finally come - or gone? Global Media and Communication, 1, 385-388. https://doi.org/10.1177/1742766505058137

Men, L. R., \& Tsai, W. H. S. (2014). Perceptual, attitudinal, and behavioral outcomes of organizationpublic engagement on corporate social networking sites. Journal of Public Relations Research, 26, 417-435. https://doi.org/10.1080/1062726X.2014.951047

Men, L. R., \& Tsai, W. H. S. (2016). Public engagement with CEOs on social media: motivations and relational outcomes. Public Relations Review, 42, 932-942. https://doi.org/10.1016/j.pubrev.2016.08.001

Morehouse, J., \& Saffer, A. J. (2019). Illuminating the invisible college: an analysis of foundational and prominent publications of engagement research in public relations. Public Relations Rewiew, 45, 101836. https://doi.org/10.1016/j.pubrev.2019.101836

Oliveira, A., \& Capriotti, P. (2019). the purpose of public relations: from persuasion to mutual influence. Comunicacio-Revista de Recerca I D Analisi, 36, 53-70. 
Page, J. T., \& Parnell, L. J. (2018). Introduction to strategic public relations - digital, global, and socially responsible communication (1st ed.). SAGE Publications.

Rubtcova, M., \& Pavenkov, O. (2018). Methods and tools of public relations' technologies. In International Conference on Global Business, Economics, Finance and Social Sciences (ICGBEFSS), Deheradun, Uttarakhand, India. https://ssrn.com/abstract=3265986

Saxton, G. D., \& Waters, R. D. (2014). What do stakeholders like on Facebook? Examining public reactions to Nonprofit organizations' informational, promotional, and community-building messages. Journal of Public Relations Research, 26, 280 299. https://doi.org/10.1080/1062726X.2014.908721

Smith, B. G. (2010). Socially distributing public relations: Twitter, Haiti, and interactivity in social media. Public Relations Review, 36, 329-335. https://doi.org/10.1016/j.pubrev.2010.08.005

Smith, R. D. (2017). Strategic planning for public relations (5th ed.). Taylor \& Francis Ltd. https://doi.org/10.4324/9781315270876

Sommerfeldt, E. J., \& Yang, A. (2018). Notes on a dialogue: twenty years of digital dialogic communication research in public relations. Journal of Public Relations Research, 30, 59-64. https://doi.org/10.1080/1062726X.2018.1498248

Sommerfeldt, E. J., Yang, A., \& Taylor, M. (2019). Public relations channel "repertoires": exploring patterns of channel use in practice. Public Relations Review, 45, 101796.

https://doi.org/10.1016/j.pubrev.2019.101796

Taylor, M., \& Kent, M. L. (2014). Dialogic engagement: clarifying foundational concepts. Journal of Public Relations Research, 26, 384-398. https://doi.org/10.1080/1062726X.2014.956106

Tetrevova, L. (2018). Communicating CSR in high profile industries: case study of Czech chemical industry. Inzinerine Ekonomika-Engineering Economics, 29, 478-487. https://doi.org/10.5755/j01.ee.29.4.19199

Tetrevova, L., Patak, M., \& Kyrylenko, I. (2019). Webbased CSR Communication in Post-communist countries. Applied Economics Letters, 26, 866871. https://doi.org/10.1080/13504851.2018.1508866

Theunissen, P., \& Noordin, W. N. W. (2012). Revisiting the concept "Dialogue" in public relations. Public Relations Review, 38, 5-13.

Tworzydlo, D. (2016). Public relations - the tools for unilateral communication and dialogue on the internet. INIB, 20, 79-90.

https://www.degruyter.com/downloadpdf/j/minib.2 017.20.issue-2/minib.20.03.2016.11/minib.20.03. 2016.11.pdf

Yuan, E. (2011). News consumption across multiple media platforms: a repertoire approach. Information, Communication \& Society, 14, 998-1016. https://doi.org/10.1080/1369118X.2010.549235 